\title{
announcements
}

\section{On the Move}

T. J. Martin, Professor of Chemical Pathology, University of Sheffield, to Professor of Medicine, University of Melbourne, Repatriation General Hospital, Australia, from 1 October 1977.

N. H. Hunt, Department of Chemical Pathology, University of Sheffield, to Department of Experimental Pathology, John Curtin School of Medical Research, A.N.U., Australia.

Details of changes of department, sabbaticals, where leave will be taken and so on chould be charge for this service.

\section{Appointments}

Dr D. F. Hornig, President-emeritus of Brown University to Professor of Chemistry in Harvard Faculty of Public Health to direct development of a proposed University-wide undertaking, Interdisciplinary Programs in Health.

Mr L. R. Hanton, University of Otago, New Zealand, to a Rutherford Scholarship for three years from 1 October 1977 to work in the department of organic and inorganic chemistry, University of Cambridge.

\section{Awards}

Dr D. Schofield, chief of the Defence Research Establishment at Dartmouth, N.S. to deputy chief of laboratories, responsible for all Department of National Defence research establishments. Dr Schofield will be replaced by F. A. Fergusson, Deputy Chief in Ottawa.

Dr S. Weinberg, Higgins Professor of Physics at Harvard University and Senior Scientist at the Smithsonian Astrophysical Observatory, is the 1977 winner of the American Institute of Physics-United States Steel Foundation Science-Writing Award $(\$ 1,500)$ for his book, 'The First Three Minutes', relating the theory of elementary particles to the problem of the very early moments of the Universe.

\section{The British Council \\ East European Exchange Visits}

Cultural agreements with the Soviet Union, Czechoslovakia, Hungary, Romania and Bulgaria provide for short visits (usually 2 weeks) and medium term research visits (2-6 months) for British scientists. Scholarships are also available for periods of up to one academic year. For full details and application form, contact Higher Education and Science Department, The British Council, 10 Spring Gardens, London SW1, UK.

\section{Meetings}

21-22 October, International Symposium on Chromogenic Substrates, London (Thrombosis Research Unit, Department of Surgery, Denmark Hill, London SE5, UK).

2-4 November, Symposium on Advanced Ozone Technology, Toronto (A. Netzer, Head, Physical Chemical Processes, Wastewater Technology Center, Canadian Center for Inland Water, PO Box 5050, Burlington, Ontario, Canada).

2-5 November, Symposia on Perspectives in Biochemistry, and Isoenzymes, Cordoba, Argentina (R. Caputto, Departamento Quimica Biologica, Facultad de Ciencias Quimicas, Univeridad Nacional de Cordoba, Ciudad Universitaria, 5000-Cordoba, Argentina).

9 November, Liquid Crystals, London, UK (The Institute of Physics, 47 Belgrave Square, London SW1, UK).

9 November, Symposium on Humidity Measurement, London, UK Sira Institute Ltd, South Hill, Chislehurst, Kent, UK).

\section{Person to Person}

Mathematician seeks family accommodation in Oxford, January to December 1978, or exchange house in Newcastle, N.S.W., Australia. Contact W. Brisley, Mathematics Department, University of Newcastle, N.S.W. 2308, Australia.

$$
\begin{aligned}
& \text { There will be no charge for this service. } \\
& \text { Send items (not more than } 60 \text { words) to } \\
& \text { Marcus Dobbs at the London office. The } \\
& \text { section will include exchanges of accommo- } \\
& \text { dation, personal announcements and scientific } \\
& \text { queries. We reserve the right to decline } \\
& \text { material submitted. No commercial trans- } \\
& \text { actions. }
\end{aligned}
$$

10-12 November, Open Conference on the Implications of Recombinant DNA Research, Bloomington, Indiana (Professor R. P. Bareikis, The Poynter Center 410 North Park Street, Bloomington, Indiana 47401).

14-15 November, New Developments in Immunoassays, Düsseldorf (M. A. Andreopoulos, Conference Director, Robert S. First, Inc., Avenue Marnix 19A, Box 6, 1050 Brussels, Belgium) (also in Chicago, 5-6 December).

14-15 November, Symposium on Mass Spectrometry and Combined Techniques in Medicine, Clinical Chemistry and Clinical Biochemistry, Tübingen (Medizinische Klinik, Universität Tübingen, Otfried-Müller-Strabe 10, 7400 Tübingen, GFR).

14-17 November, International Symposium on the Pineal Organ, Jerusalem (I. Nir, Faculty of Medicine, Hadasseh Medical School, Jerusalem, Israel).

14-18 November, The Pan American Conference on Forensic Applications of Anthropology, Dentistry, Medicine and Palaeopathology, Mexico City (W. G. Eckert, Laboratory, St Francis Hospital, Wichita, Ks. 67214).

17-18 November, Symposium on Nutritional Management of Genetic Disorders, New York (The National Foundation-March of Dimes, 622 Third Avenue, New York, N.Y. 10017). 21-26 November, Fif th International Conference on Global Impacts of Applied Microbiology, Bangkok (Chairman, GIAM V, National Organising Committee, Mahidol University, GPO Box 4-130, Bangkok, Thailand).

22-23 November, Symposium on Photography in the Laboratory, London (The Secretary, Scientific Symposia Ltd, 4243 Gerrard Street, London W1, UK).

\section{Reports and Publications Other Countries-July}

United States Department of the Interior: Geological Survey. Professional Paper 655-M: Effects of Phreatophyte Removal on Water Quality in the Gila River Phreatophyte Project Area, Graham County, Arizona. By R. L. Laney. Pp. iv $+23+2$ plates. (Washington, DC: US Government Printing Office, 1977.) [117 CERN - European Organization for Nuclear Research. CERN 77-10: Selection of Formulae Concerning Proton Storage Rings. By G. Guignard. Pp. $x+108$. (Geneva: CERN, 1977.) [117 Deutsches Hydrographisches Institut, Hamburg. 29./30. Jahresbericht 1974/1975. Pp. 134. (Hamburg: Deutsches Hydrographisches Institut, 1977.) [127 Bayer 1976. Pp. 103. (Leverkusen: Bayer Aktien-
[127 geselischaft, 1977 .
National Multiple Sclerosis Society. 1976 Annual National Multiple Sclerosis Society. 1976 Annual
Report. Pp. 32. (New York: National Multiple Report. Pp. 32. (New York: National Multiple
Sclerosis Society, 205 East 42nd Street, 1977.) Sclerosis Society, 205 East 42nd Street, 1977.) $[137$
CERN - European Organization for Nuclear CERN - European Organization for Nuclear
Research. CERN 77-11: Future Photomultiplier Research. CERN 77-11: Future Photomultiplie Assemblies and Associated Electronics in Large Innocenti, A. Michelini, B. Smith and F. Soso. Innocenti, A. Michelini, B. Smith and F. Soso.
[147 United States Department of the Interior: Geological Survey. Bulletin 1422-B: The Maudlow and Sedan Formations of the Upper Cretaceous Livingston Group on the West Edge of the Crazy Mountains
Basin, Montana. By Betty Skipp and L. W. McGrew. Basin, Montana. By Betty Skipp and L. W. McGrew. and Petrology of the Precambrian Crystalline Rocks, Park and Jefferson Counties, Colorado. By C. C. Hawley and R. A. Wobus. Pp. v $+77+$ plate 1 . Professional Paper 984: Geology of an Upper Cretaceous Copper Deposit in the Andean Province, Lassiter Coast, Antarctic Peninsula. By Peter D. Rowley, Paul L. Williams and Dwight L. Schmidt. Pp. vi +36 . (Washing tion, DC: US Government Printing Office, 1977.) [147 Mitteilungen aus der Biologischen Bendesanstalt fü Land- und Forstwirtschaft, Berlin-Dahlem. Heft 174 Gaschromatographie der Pflanzenschutzmittel-Tabellarische Literaturreferate VI; Kumulative Indices 1-Vl. Von Dr. Winfred Ebing. Pp, 102. (Berlin-Dahlem: Biologischen Bindesanstalt für Land- und Forstwirtchaft, 1977.) DM 17.50.

Journal of Mechanical Working Technology, Vol. I Annua Subscion. Annual Subscription: Df. 155; \$58.95. (Amsterdam 